\section{FOUNDATIONS OF NEUROPSYCHIATRY}

By Stanley Cobb, A.B., M.D. 5th Edition. Pp. $x+287$, with 15 illustrations. London: Baillière, Tindall \& Cox. 1952. 24s.

This well-known text has been largely rewritten since its last edition, and a new chapter on general neurophysiology has been added.

Of its I4 chapters, II are concerned with the anatomy and functions of the nervous system, and the account of these is straightforward and concise. The chapter on 'Motor integration and locomotion' is admirably lucid, and Dr. Cobb's high standing as a neurologist is reflected in his exposition of the principles of nervous activity.

The psychiatric chapters are less commendable. They are too few in number-only three-and the writing is uncertain and over-simplified. The author gets into difficulty with the concept of the unconscious, and teaches that consciousness is a matter of degree, though he describes the mechanism of repression and admits the existence of unconscious motivation.

The book is a useful elementary introduction to the study of neurology for senior students, and contains enough allusion to psychodynamics to whet the appetite for stronger meat.

\section{D.O'N.}

\section{TOPICS IN PHYSICAL CHEMISTRY}

By W. Mansfield Clark, Ph.D., Sc.D. 2nd Edition. Pp. xviii +777 , with 176 illustrations. London: Baillière, Tindall \& Cox. 1952. 76s. 6d.

A knowledge of the general principles of physical chemistry is the basis of an understanding of all biological science. Professor Clark has taken a number of important topics in physical chemistry and discussed them lucidly and with great insight into what are the probable gaps in the scientific education of his readers who are predominantly medical students, both undergraduate and graduate. One finds in this book an enormous store of valuable information which is authoritative, up-to-date and very relevant to the problems which may confront any scientist, but especially the biologist. It is not intended to be a text-book of biochemistry. The text is not overloaded with applications showing the practical value of the principles discussed, nor is it severely academic and abstract. The erudite and masterly style make this book one of the comparatively few scientific texts which it is a pleasure to read. Where the author has found it necessary in the interests of space to condense his material, he has clearly indicated this and given the reader wise directions as to where he may find an adequate discussion of the subject.

The first edition of this book was of great benefit to a large circle of readers, students, teachers and research workers alike. This edition, published four years later, has enabled some revisions of the text to be made and some useful additions of recent material. It will thoroughly deserve continued success.

\section{SCOLIOSIS-PATHOLOGY, AETIOLOGY ANDz TREATMENT}

By Samuel Kleingerg, M.D. Pp. $\mathrm{xv}+286$, with I 63 illustrations. London: Baillière, Tindall $8 \overrightarrow{\mathrm{F}}$ Cox, I 95 I. 57s. 6d.

Dr. Kleinberg has undertaken a revision of hiso book on scoliosis published 25 years ago. Such haven been the changes in our views on the subject that it is not surprising he found it necessary to rewrite many chapters, and the present monograph ise practically a new book.

There are valuable chapters on Anatomy; Classification and Aetiology. The classification adopted in perhaps more elaborate than we areg accustomed to nowadays, but has the virtue of completeness; the aetiology of so-called idiopathic 3 scoliosis remains obscure, in spite of the great pre ponderance of this group of cases. We find in the book a mixture of old and new fashions and beliefs this tendency becomes most apparent in the section on treatment, where the author shows some divergence from the modern view in believing that corrective gymnastic exercises can prevent a curve from increasing, neither does he insist that spinaP fusion is necessary to consolidate the correction obtained by forcible methods. He uses beef bonep in his operation for spinal fusion, and does not refer to refrigerated human bone.

However, the modern views in these matters are not yet fixed, and the opinion of a man of th author's experience must receive respectful con- -0 sideration. The appearance, lay-out and illust tions are very satisfactory, but the price is rathex high for a book of this kind in this country.

W.D.C

\section{INTRODUCTION TO DENTAL ANATOMY}

By James H. ScotT, B.Sc., M.D., L.D.S., and NoRMan B. Symons, M.Sc., B.D.S. Pp. 292, 영 with 172 illustrations. Edinburgh: E. \& $S_{5}$ Livingstone Ltd. I 952 . $35 \mathrm{~s}$.

There must always be some division of opinions about a textbook which departs from the orthodox 3 It is not unreasonable for an author to print his ownotheories on controversial matters but for the sake of a student not of his university it should be madei abundantly clear that other views are also held and these possibly by his examiners. A bibliography at the end of each chapter, however complete, is not sufficient as the time and inclination of the averager student is limited and only the post-graduate will seek out more information than that which is placed, directly in his line of vision.

These faults apart the book is very well composed and the illustrations make it outstanding in works of its class. Both authors are distinguished in theirs fields and any work of theirs can be read witk advantage.

The publishers are also to be congratulated on yet another distinguished contribution to the dentaP literature.

S.R. 